\title{
"Sometimes a Bee Can Move an Ox": Biblical Epics and One Man's Quest to Promote Jewish Values in Blacklist-Era Hollywood
}

\author{
Andrew Paul
}

In the 1950s, the top American Jewish organizations chose a single man, John Stone, to represent their collective interests in Hollywood. Over the course of the decade, Stone's Motion Picture Project sought to prevent antisemitism on film and to inspire the creation of positive Jewish characters. Negotiating the cultural politics of the era, however, resulted in an increasing tendency to favor depictions of biblical Jews over contemporary American ones. In a strange twist, Stone endorsed no film with as much zeal as Ben-Hur, a New Testament celebration of Jesus. By following Stone's tortuous attempts to navigate Cold War controversies, and by casting new light on the phenomenal success of biblical epics in the 1950s, this essay suggests that at the heart of postwar popular culture was a shift toward a particular discourse of liberal humanism.

In a memorable scene from Joel and Ethan Coen's film, Hail, Caesar! (2016), Hollywood producer Eddie Mannix assembles various men of faith to preview his studio's upcoming period piece about Jesus and the crucifixion. This film within a film is a riff on the biblical epics that movie studios churned out in the 1950s, movies such as Quo Vadis (1952) and Ben-Hur (1959). After viewing the film, the Catholic, Protestant, Eastern Orthodox, and Jewish clergymen take turns commenting on whether this product of mass industrial entertainment offends or enlightens in its handling of faith. No one is more cantankerous than the rabbi, played by Robert Picardo. As the other men debate the nature of the relationship between Jesus and God, and how it should be portrayed on screen, the rabbi derides all of his New Testament-reading colleagues as "screwballs." "God doesn't have children, God's a bachelor," he insists. When the Catholic priest reports to Mannix that the film reflected "tastefulness and class," the rabbi shouts out, "Who made you the expert all of a sudden?"

In Hollywood's "studio era," producers and moguls often did seek expert feedback from religious figures-clergy and laypersons-and from all kinds of other interest groups and government offices. The story behind how American Jews in particular sought to influence Hollywood lies in the heretofore unstudied files of one man, John Stone. Though Jewish, Stone was not a rabbi like the character in Hail, Caesar! He was a retired movie producer, chosen by an umbrella group representing the country's most influential liberal secular Jewish organizations_-including the Anti-Defamation League (ADL), the American Jewish Congress, the American Jewish Committee, the Jewish Labor Committee, and the Jewish War Veterans-to be their man in Hollywood. Liberal Jewish organizations traditionally bestowed awards or stamps of approval onto films that portrayed Jews positively or undertook to represent social problems. But never before had all of these Jewish organizations united in an

I would like to thank Joseph Haker and Nate Holdren for their feedback on an early draft; my anonymous readers, who provided substantive and valuable suggestions; and Sarah Phillips and Brooke Blower at $M A H$, who showed great attention and care in ushering this essay through to publication.

${ }^{1}$ Hail, Caesar!, dir. Ethan Coen and Joel Coen (Universal Pictures, 2016).

(c) The Author(s) 2018. Published by Cambridge University Press 
attempt to speak to Hollywood with one authoritative voice. Stone's new undertaking, dubbed "the Motion Picture Project," brought him in close contact with the studios as they made their films; he read their scripts and consulted with producers before the cameras even began rolling.

Stone's tenure coincided with that of Hollywood's red scare. During the blacklist era, ideas about both liberalism and Jewishness became inseparable from the politics of anti-communism. And Stone's mission, to encourage the studios to promote tolerance and to place Jews on screen in positive roles, was shaped by this Cold War conundrum. When the Motion Picture Project began in the late 1940s, Stone's most pressing concern was that Hollywood might make movies about Jesus, portraying Jews as the cause of his death. He hoped that the studios might instead produce films of contemporary social relevance-ones that tackled antisemitism such as Gentleman's Agreement (1947), as well those that centered on the experiences of African Americans and other minorities. But during the 1950s, he struggled to find and articulate a cinematic vision that both offered admirable contemporary social portraits and avoided the era's anti-communist lightning rods.

As a surprising solution, the Motion Picture Project embraced Hollywood's biblical epics, movies that Stone at one time feared would be hokey at best, and at worst, reminiscent of passion plays. Indeed, by the late 1950s, biblical epics were just about the only kind of movie that the major liberal Jewish organizations endorsed without reservations. Stone raved about all kinds of biblical epics from the Old Testament saga The Ten Commandments (1957) to the New Testament-inspired The Silver Chalice (1954). Stone even went so far as to declare Ben-Hur-a film bearing the subtitle "A Tale of the Christ"- to be "the greatest Jewish document in the history of the cinema." Biblical epics, Stone had discovered, provided the perfect vehicle for showing Jews on screen without depicting them as immigrants, minorities, workers, or radicals, in other words the kinds of figures so often singled out as communists or communist sympathizers. ${ }^{2}$

Biblical epics were Hollywood's most successful products of the 1950s, in large part because the genre capitalized upon and helped to circulate a nascent political-cultural language: that of liberal humanism. Previous forms of liberalism-born amid depression-era Popular Front politics, swirling with cultural relativism and other progressive sociological currents-encouraged a worldview attentive to the role of experience, social conditions, and structures as forces that shaped the actions and perspectives of individuals and groups. But amid the violence and totalitarianism of the early 1940s, prominent thinkers began to turn away from these kinds of intellectual approaches. As Mark Greif has argued, by the postwar period many intellectuals and artists shared a preoccupation with the elevation of the individual man's innate freedom to act, unencumbered by coercive forces. A common "fear of organization and conformism," and a kind of anti-authoritarian liberal humanism, ran through the philosophical sensibilites of the era, suffusing not just intellectual discourse but also broader American popular culture. This new orientation centered upon the belief that human beings could be freed from modernity if they were primed to operate on the basis of strong and moral individual wills. If the enemy of progress was "organization," its savior was the "unmarked, universal man"-an ideal form free from modern state institutions or social incumbrances. ${ }^{3}$

In some ways an understandable response to the horrors of World War II, liberal humanism was nevertheless ill-suited to the continuing problems of social, economic, and racial injustice. Advocates of this liberal individualist perspective favored a conception of freedom as "negative," which meant that institutions should gain influence or power only insofar as they freed individuals to act without coercion, and governed to maximize individualistic thought and behavior. As a result, Jewish liberal organizations and intellectuals dedicated to solving "intergroup"

\footnotetext{
${ }^{2}$ John Stone, Report \#133, May 4, 1960, folder 12, box 43, National Jewish Community Relations Advisory Council Papers, American Jewish Historical Society, New York City, NY (hereafter cited as NJCRAC-AJHS).

${ }^{3}$ Mark Greif, The Age of the Crisis of Man: Thought and Fiction in America, 1933-1973 (Princeton, NJ, 2015), $32-3,85,87-8$.
} 
social problems, but who favored liberal humanist ways of thinking, skirted discussions of race, cultural difference, or religious particularities. Stuck in the position of working towards better conditions for particular groups while having to deny the importance of difference among groups, liberal Jewish organizations could only advocate for the positive portrayals of individuals. That meant rejecting the presence of Jews in any pictures with anything resembling a contemporary social context. ${ }^{4}$

During the 1950s, like others, Stone came to see Popular Front liberalism as an impractical vehicle for advancing Jewish and "intergroup" interests. By accepting the discourse of liberal humanism, by championing its appearance on screen, and by wedding such a language to a conception of "Jewish values," he took part in the elevation of a powerful set of symbols and narratives that helped to define the bounds of postwar liberalism, not only among liberal Jews but other Americans as well. ${ }^{5}$

In Hollywood historiography, it is standard practice to make an argument about whether or not-or to what degree- the culture of the movie industry shifted to the right during the blacklist era. Nearly every history of the period tells the story as a tale of warring left and right factions, each beholden to certain static and immutable ideologies. In this standard telling, a pro-labor, pro-civil rights, civil libertarian, and anti-authority left pits off against a conservative, pro-business, anti-union, racist, antisemitic, and anti-civil-liberties right. Each side sought to move the needle in its direction. The perennial question, then, is how far the needle actually moved. ${ }^{6}$

But John Stone's story offers an opportunity to reorient the historiography around a more critical method of reading blacklist-era culture: one that moves beyond a simple dichotomy between left and right by investigating how the period's battles birthed a nascent liberal humanist language-one that gained traction across the political spectrum. Combining individualism with anti-statism and civil libertarianism, liberal humanism offered a widely useful resolution to the ideological crisis of the 1950s. Culture works in funny ways, at times at cross-purposes to its creators. Symbols change meaning, and in the words of Kenneth Burke, are stolen "back and forth." In this way, artistic creations of leftists and left-liberals during the 1950s, though made in response to victimization by the anti-communist state, reflected and contributed to an

\footnotetext{
${ }^{4}$ Ibid.

${ }^{5}$ On Popular Front politics in the United States, see Michael Denning, The Cultural Front: The Laboring of American Culture in the Twentieth Century (New York, 1998) and Doug Rossinow, Visions of Progress: The Left-Liberal Tradition in America (Philadelphia, 2008). This essay treats liberalism in the sense that Lisa Duggan has called "capital 'L' Liberalism," one entirely different than that used in popular media today. See Lisa Duggan, The Twilight of Equality? Neoliberalism, Cultural Politics, and the Attack on Democracy (Boston, 2003); Alan Brinkley, The End of Reform: New Deal Liberalism in Recession and War (New York, 1995); and Doug Rossinow, "Partners for Progress? Liberals and Radicals in the Long Twentieth Century," in Making Sense of American Liberalism, eds. Jonathan Bell and Timothy Stanley (Urbana, IL, 2012), 17-37.

${ }^{6}$ The seminal work on the Hollywood blacklist remains Larry Ceplair and Steven Englund, The Inquisition in Hollywood: Politics in the Film Community, 1930-1960 (Garden City, NY, 1980). For more recent treatments, see Reynold Humphries, Hollywood's Blacklists: A Political and Cultural History (Edinburgh, UK, 2010); Michael Freedland, Hollywood on Trial: McCarthyism's War Against the Movies (London, 2007); John Sbardellati, J. Edgar Hoover Goes to the Movies: The FBI and the Origins of Hollywood's Cold War (Ithaca, NY, 2012); Lary May, The Big Tomorrow: Hollywood and the Politics of the American Way (Chicago, 2000); Steven J. Ross, Hollywood Left and Right: How Movie Stars Shaped American Politics (New York, 2011); and Donald T. Critchlow, When Hollywood Was Right: How Movie Stars, Studio Moguls, and Big Business Remade American Politics (New York, 2013).

${ }^{7}$ Kenneth Burke, Attitudes Toward History, 3rd ed. (Berkeley, CA, 1984), 141. Examples of the tendency of scholars to ascribe resistance to blacklistees in the entertainment industry include Paul Buhle and Dave Wagner, Hide in Plain Sight: The Hollywood Blacklistees in Film and Television, 1950-2002 (New York, 2003), and Brenda Murphy, Congressional Theatre: Dramatizing McCarthyism on Stage, Film, and Television (New York, 1999).
} 
anti-statism that might be read as right-wing libertarian today. ${ }^{8}$ John Stone and his colleagues were not so much victims of the blacklist as adjacent to it, encouraging and nurturing the liberal humanist discourse of cinematic Biblical epics.

Stone's story also raises questions about American religious history narratives. Recent examinations of post-World War II liberal Protestantism have highlighted the flourishing of a liberal pluralism, or a "spiritual cosmopolitanism," that appears not only to have expanded the boundaries of belonging to include religious minorities, but also to have "softened the ground" for the civil rights movement. ${ }^{9}$ These narratives describe the liberalism of prominent civic religious groups as separate from the harsher "laissez-faire liberalism" of conservatives and libertarians. ${ }^{10}$ Yet the story of John Stone and the Motion Picture Project might give us pause in seeing midcentury liberalism as simply an inevitable resolution of the promise of American democracy, or something distinct from the individualism of contemporary culture. Placing liberal humanism at the center of a discussion about postwar culture illustrates the protean nature of liberalism; yet it also shows how its enduring core-the ideas of natural rights and individualism-shaped and limited American imaginations. ${ }^{11}$

In 1944, the major Jewish American interest groups, including the Anti-Defamation League, the American Jewish Congress, the Jewish War Veterans, and the American Jewish Committee, arrayed under an umbrella organization called the National Community Relations Advisory Council (NCRAC). The NCRAC also entered into relationships with dozens of state and local Jewish community councils. The NCRAC hoped to "serve as a co-ordinating and clearance agency for projects and policies, to eliminate duplication and conflict of activities, and to recommend further projects to member agencies." As an assemblage of what were generally termed "intergroup relations" organizations, these projects tended to center around the problems of antisemitism and ethnic and racial bigotry. ${ }^{12}$

Among its many initiatives that sought to coordinate national Jewish interests, the NCRAC created a Committee on Mass Media, operating out of New York City, and then in 1946 conceived of a subordinate, Los Angeles-based Motion Picture Committee, believing that its best hope to influence popular culture would be by speaking to Hollywood with one voice. The project began operating two years later and continued into the 1960 s. $^{13}$

The new NCRAC incorporated one longstanding, local Jewish community council, the Los Angeles Community Relations Committee (LA-CRC). Because of its location, and because its membership included men who worked in Hollywood, the LA-CRC naturally had been lobbying movie studios since the 1930s. But the Motion Picture Project, as envisioned by the NCRAC, represented a new idea: a mechanism by which Jews would give advice and approval

\footnotetext{
${ }^{8}$ For an examination of leftist blacklisted writers who created anti-statist and libertarian popular culture in the 1950s, see Andrew Paul, "Reassessing Blacklist Era Television: Civil Libertarianism in You Are There, The Adventures of Robin Hood, and The Buccaneers," American Studies 54, no. 1 (2015): 29-52.

${ }^{9}$ Matthew S. Hedstrom, The Rise of Liberal Religion: Book Culture and American Spirituality in the Twentieth Century (New York, 2013), 10, 216; Kevin M. Schultz, Tri-Faith America: How Catholics and Jews Held Postwar America to Its Protestant Promise (New York, 2013), 185.

${ }^{10}$ Hedstrom, The Rise of Liberal Religion, 8-9; David A. Hollinger, After Cloven Tongues of Fire: Protestant Liberalism in Modern American History (Princeton, NJ, 2013).

${ }^{11}$ I borrow the descriptor "protean" from Gary Gerstle, "The Protean Character of American Liberalism," American Historical Review 99, no. 4 (Oct. 1994): 1043-73.

12“Guide to the Records of National Jewish Community Relations Advisory Council 1940-1994," American Jewish Historical Society, 2017, http://digifindingaids.cjh.org/?pID=365502 (accessed Dec. 23, 2017).

${ }^{13}$ Nathan Katz, memorandum, Sept. 9, 1946, folder 1, box 40, NJCRAC-AJHS; John Stone, Report \#1, folder 5, box 43, NJCRAC-AJHS.
} 
on scripts as they were being considered and produced. The organizers imagined it would serve as analogue to the Catholic Legion of Decency, which had exerted pressure on Hollywood since the 1930s by instituting a ratings system. The Motion Picture Project's power could only come from something as formidable as the new NCRAC; instead of being one of the many small offices of competing Jewish interests like the LA-CRC, it would represent all of the nation's liberal Jewish organizations and communities. Some evidence suggests that the NCRAC might also have had something of an ulterior motive: to wrest control over matters of national importance from its counterpart Jews in Los Angeles. ${ }^{14}$

The Motion Picture Project was at its heart a one-man operation. NCRAC officials appointed John Stone (né Strumwasser), a retired motion picture producer, as the Executive Director of the Motion Picture Committee as well as the group's official liaison in Hollywood. They selected Stone because he had connections in both the film industry as well as the Los Angeles Jewish community; in fact, he was one of the co-founders of Hollywood's Temple Israel, established in 1926. Stone set up shop in the offices of LA-CRC, where Hollywood producer (and later president of the ADL) Dore Schary headed its own small counterpart to the Motion Picture Committee. Stone began apprising the NCRAC of Hollywood films in the making and reporting on his meetings with various film studio executives and producers. He envisioned three main functions for the Motion Picture Project: first, as a "focal clearing point for all matters of Jewish import as depicted on the screen"; second, as a "center from which could be mustered all the aid and advice the studios may need in any situation affecting proper community relations"; and third, as "the agency through and by which the studios could avoid censorship and improve their public relations with a large and influential group."15

The NCRAC gave Stone "discretionary power" and "considerable leeway in his activities in the studios, and the Motion Picture Association." If he encountered any serious problems with any of the studios, he was to contact Mendel Silberberg, the chairman of the LA-CRC, or the members of the NCRAC Motion Picture Committee in New York. Otherwise, Stone was directed to notify the NCRAC about "the details of any proceedings that he will conduct; and whenever necessary ... avail himself of advice from the various national agencies, through NCRAC channels." The NCRAC intended to ensure that Stone's voice competed with no others, and for Stone to hear from none other than the NCRAC. Furthermore, the NCRAC also asked the Central Conference of Rabbis to defer to Stone when it came to the movies, granting that Stone would seek "advice and information on all questions of religious import" from them as necessary. ${ }^{16}$

Stone and the Motion Picture Project's relationship with Jewish intergroup organizations quickly grew complicated. In 1952, not long after Stone began his work, the ADL and the American Jewish Committee left the NCRAC, and it looked as though the project might fall apart. Scrambling to ensure that Stone's position could remain funded and uncontested, in 1953 Chairman of the NCRAC Motion Picture Committee Bernard Trager made the Motion Picture Project technically "autonomous" of the NCRAC so that the ADL and the American Jewish Committee could remain contributors, and perhaps more importantly, so that Stone could maintain his status as the Jewish community's singular voice in Hollywood. Trager proposed that Stone's Los Angeles office replace both the NCRAC's New York-based Motion Picture Committee as well as that of the LA-CRC, although in practice Schary continued to

\footnotetext{
${ }^{14}$ Neal Gabler, An Empire of Their Own: How the Jews Invented Hollywood (New York, 1989), 302, 305; NRCAC Mass Media Committee on Motion Pictures meeting minutes, Sept. 18, 1947, folder 1, box 40, NJCRAC-AJHS.

${ }^{15}$ Gabler, An Empire of Their Own, 306; Minutes of NCRAC Motion Picture Committee Meeting, Nov. 15, 1948, folder 1, box 40, NJCRAC-AJHS; "History of NCRAC's Hollywood Project," June 23, 1949, folder 1, box 44, NJCRAC-AJHS; Stone, Report \#1, NJCRAC-AJHS.

${ }^{16}$ Stone, Report \#1, NJCRAC-AJHS.
} 
operate his Motion Picture Committee alongside Stone's. ${ }^{17}$ Its institutional structure clarified and its finances secured, the Motion Picture Project thus set out to encourage the positive depiction of Jews in cinema and to prevent stereotypes and derogatory portrayals from being shown on screen.

Recent films offered both negative and positive models. For example, NCRAC members took offense to Abie's Irish Rose (1946), the story of a Jewish man who marries a Catholic woman, which pulled laughs with one-dimensional ethnic caricatures. Worse was the 1948 adaptation of Oliver Twist, which depicted Charles Dickens's notorious villain Fagin with crude, even grotesque, antisemitic stereotypes. ${ }^{18}$ The same period, however, had also produced more welcome portraits of Jews. Gentleman's Agreement (1947) offered both a study in antisemitism and a complicated look at identity-its social construction and its intersection with class inequality. In one scene a Jewish scientist, a ringer for Albert Einstein, tells the story's goyish protagonist that he identifies as Jewish not because of religion or biological difference, but rather because it was a moral imperative to be counted among them. And the film ends with a rousing monologue that invokes the "century of the common man" of the progressive (and soon to be red-baited) Henry Wallace. The similarly successful Body and Soul (1947), directed and written by communists Robert Rossen and Abraham Polonsky, offered an anti-capitalist allegory starring John Garfield (né Julius Garfinkle) as the son of immigrants who becomes a fighter in order to rise out of his ethnic neighborhood, but finds himself the victim of unscrupulous exploiters. Both of these social realist films, produced just before the onset of the red scare and informed by the left-liberal culture of the Popular Front, drew acclaim from liberal and socialist Hollywood activists as well as the NCRAC, which, at least at first, aspired to see more such roles emerge from Hollywood. ${ }^{19}$

But as Cold War anxieties simmered, disagreements erupted over what exactly constituted a positive portrayal of Jews, and some wondered if it was a good idea to push for more Jewish characters on the big screen. Mendel Silberberg of the LA-CRC, for example, argued for a more "quiet" approach. In September 1947, he cautioned the NCRAC that "it would be unfortunate if Hollywood were to place too much emphasis on Jewish issues." Even after Hollywood's rapturous reception of the film Gentleman's Agreement and its Academy Award for Best Picture, concerns about bringing too much attention to Jews persisted among members of both the LA-CRC and the NCRAC's Mass Media Committee. ${ }^{20}$ Both Gentleman's Agreement and Body and Soul had drawn the scrutiny of the FBI. ${ }^{21}$

The Motion Picture Project's other primary goal seemed simple in its premise: to promote the development of films that would contribute to tolerance and equality for all racial and ethnic minorities. As Stone's colleague Schary declared before the ADL in a 1948 address: "You can have no Jewish problem where you do not have a Negro problem, a Mexican problem ... or any other minority problem." Schary's statement appealed to liberal Jews. Common

\footnotetext{
${ }^{17}$ Stuart Svonkin, Jews Against Prejudice: American Jews and the Fight for Civil Liberties (New York, 1997), 73; Bernard Trager to Dore Schary, Mar. 27, 1953, folder 5, box 44, NJCRAC-AJHS; Bernard Trager to NCRAC Motion Picture Committee, Aug. 20, 1953, folder 6, box 44, NJCRAC-AJHS; Mendel Silberberg to Jacob Blaustein, Henry Schultz, and Bernard Trager, Sept., 18, 1953, folder 6, box 44, NJCRAC-AJHS.

${ }^{18}$ Minutes of Meeting of Mass Media Committee on Motion Pictures, May 31, 1950, folder 1, box 44, NJCRAC-AJHS.

${ }^{19}$ Sbardellati, J. Edgar Hoover Goes to the Movies, 103-4, 144, 152; Gordon Kahn, Hollywood on Trial: The Story of the 10 Who Were Indicted (New York, 1948), 3, 192; “'Un-American' Committee Aiming at Control Content in Film and Hiring of Film-makers," The Other Side of the Story, Hollywood, CA, Oct. 29, 1947, folder 18, box 4, Hollywood Democratic Committee Papers, Wisconsin Historical Society, Madison, WI (hereafter HDC-WHS); Minutes of Meeting of Mass Media Committee on Motion Pictures, May 31, 1950, folder 1, box 44, NJCRAC-AJHS.

${ }^{20}$ Minutes, Sept. 18, 1947, folder 1, box 40, NJCRAC-AJHS; Minutes of the "East-West Meeting of the Motion Picture Committee," Mar. 31, 1949, folder 2, box 40, NJCRAC-AJHS.

${ }^{21}$ Sbardellati, J. Edgar Hoover Goes to the Movies, 101, 103, 152, 200-1.
} 
thinking among organizations such as the ADL held that by promoting tolerance among all groups, American Jews could alleviate their own marginalization without worrying about the backlash that they presumed would happen if they made special cases out of themselves. Such a logic, however, was somewhat different from, and in tension with, other left-liberal Jewish positions in Hollywood, which envisioned racial and ethnic solidarity as a means to strengthen labor's power within the film industry. Indeed, the specter of labor politics would complicate matters for the Motion Picture Project as it attempted to weigh in on matters of race. $^{22}$

Once ensconced in Los Angeles, Stone discovered that he needed to respond quickly to what he called the "bumper crop" of movies about the crucifixion of Jesus. In a May 1949 report to the NCRAC, Stone cited a script called Divine Tragedy, and commented that the film was "(a) Catholic, (b) anti-humanist, (c) anti-science, and (d) containing overtones of anti-Semitism." The film, as often the case, was an independent effort that never saw completion. But Variety had reported that year that all the major studios intended to produce passion plays. In response, Stone polled the major studios about their intentions to sponsor such films. Warner Brothers responded that they had a script about the crucifixion "accumulating dust on the library shelf," where it would stay. And 20th Century Fox similarly comforted Stone: "For Christ's sake-No! We've got enough trouble without [passion plays]!"23

Concerns about passion plays abated, but not before Stone got a chance to pioneer a suite of useful tactics for dealing with them. Not two months in his position, Stone attended a screening of the rough cut of a crucifixion story called Prince of Peace, essentially the filmed version of a passion play performed annually in Lawton, Oklahoma. At the screening, Stone confronted the film's director and then wrote to the executive director of its backing company, cordially requesting that the movie be changed to place the blame for Jesus's crucifixion on Pontius Pilate rather than the Jews. ${ }^{24}$

The movie's director, Harold Daniels, came around to Stone's position. In November 1948, as the film was contracted for additional filming to complete the picture for a major 35 millimeter release, Daniels contacted Stone. According to Stone, Daniels "was greatly worried when I told him of the vigorous campaign I was going to inaugurate against the exhibition of this picture. His particular concern was with the probable effect that the appearance of his name on such a film would have on his career in Hollywood." A couple of months later, Daniels told Stone that he was trying to have his name removed entirely from the film. He also assured Stone that the scenes he found objectionable would be removed. ${ }^{25}$

Stone also traded comments with Richard Breen of the Motion Picture Association about Prince of Peace. Breen headed up the Association's powerful Production Code Administration (PCA), an industry effort to police content internally, in order to prevent material that interest groups and moral authorities might find offensive from reaching theaters. Never a "censor," the PCA was nevertheless a powerful gatekeeper, governing what made it

\footnotetext{
22“Revival of Ku Klux Klan Reported at Annual Conference of Anti-Defamation League," Jewish Telegraphic Agency, May 7, 1948, http://www.jta.org/1948/05/07/archive/revival-of-ku-klux-klan-reported-at-annual-confer ence-of-anti-defamation-league (accessed Nov. 24, 2013); folder 1, box 40, NJCRAC-AJHS; folder 2, box 40, NJCRAC-AJHS; "Excerpt from NCRAC 1953 Joint Program Plan: Recommendation in Area of Mass Media," folder 5, box 44, NJCRAC-AJHS. I use "left-liberal" broadly to refer to the coalition of New Dealers, Popular Fronters, communists, and socialists that operated in American political culture from the mid-1930s through the end of World War II, and broke up in the early years of the postwar red scare. In doing so, I borrow from Rossinow, "Partners for Progress?"

${ }^{23}$ John Stone, Report \#10, May 23, 1949, folder 3, box 43, NJCRAC-AJHS; John Stone, Report \#7, Feb. 7, 1949, folder 3, box 43, NJCRAC-AJHS.

${ }^{24}$ John Stone, Report \#2, Oct. 15, 1948, folder 3, box 43, NJCRAC-AJHS.

${ }^{25}$ John Stone, Report \#4, Nov. 15, 1948, folder 3, box 43, NJCRAC-AJHS; John Stone, Report \#6, Jan. 15, 1948, folder 3, box 43, NJCRAC-AJHS.
} 
onto the screen in light of cultural norms and institutional interests. Stone, of course, hoped that his own office would function the same way.

Breen told Stone in early 1949 that he was disappointed with the Prince of Peace, now called The Lawton Story. It had been expanded and supplemented with new footage that told a story-outside-of-the-story about the town putting on the production that would itself appear on screen. Breen reported that no Catholic or Protestant organizations would give it a stamp of approval, but neither would they make any attempts to prevent the film from being shown, nor lobby the filmmakers to cut or change any footage. Stone saw the finished film in April, and reported that although it was "mawkish" and poorly produced, the filmmakers had in fact followed through on their promise to remove the impression that Pontius Pilate sided with Jesus. It was no longer antisemitic. By June, the film was in and out of theaters and dead in the water. ${ }^{26}$

Perhaps Stone's concerns about an oncoming flood of passion plays were overblown. But perhaps also his efforts, alongside those of Breen, altered film industry history. It is easy to read Stone's reports-in which he tells of working with Breen's office and frequently dining with the heads of major studios-and see only the boasts of someone eager to prove to the NCRAC, the ADL, and the American Jewish Committee that he was making a difference and thus worth their investment. But evidence also suggests that Stone was as powerful as he claimed to be in his reports. According to a recollection of Martin Gang, American Jewish Committee member and one of the members of the LA-CRC Motion Picture Committee, Stone and the LA-CRC often told moviemakers what to change in their scripts and "they would do it." At the very least, Stone and the LA-CRC acted as translators to the film industry, promoting among Hollywood's fast-moving moguls and producers a set of broadly liberal values that expanded beyond Jewish interests. More often than not, changing the script meant eliminating small details, not adding characters or rewriting endings. But this small work was by no means inconsequential. Furthermore, Stone's greatest power may have been in dissuading the production of certain kinds of stories altogether. ${ }^{27}$

If Jewish organizations had one overriding concern in 1949 about the representations of Jews, it was not that they were depicted as Christ-killers, it was that they were conflated with communists. That summer, during the nadir of the country's second red scare, a Paul Robeson concert in Peekskill, New York erupted into violence when anti-communist rioters, shouting antisemitic and racist epithets, attacked the singer's socialist and progressive fans. But even as riot victims decried the obvious anti-black and antisemitic dimensions of the attacks, liberal Jewish organizations defensively affirmed their official anti-communist positions instead of condemning the reactionaries. The following year, the chairman of the NCRAC declared in response that "the Jewish community in America is deeply disturbed about the possible development of a general tendency spuriously to equate Jewishness with Communism or with Communist sympathy." The 1950 arrests of Julius and Ethel Rosenberg, charged with atomic espionage, added to the organization's sense of urgency about common associations between communism and Jewishness. $^{28}$

Two of John Stone's officemates at the LA-CRC's Motion Picture Committee knew keenly what it was like to be accused of communist affiliations or sympathies in the late 1940s and early 1950s. The director of the Motion Picture Committee, Dore Schary, was the vice president

\footnotetext{
${ }^{26}$ Stone, Report \#6, NJCRAC-AJHS; John Stone, Report \#9, Apr. 8, 1949, folder 3, box 43, NJCRAC-AJHS.

${ }^{27}$ Gabler, An Empire of Their Own, 303.

${ }^{28}$ Svonkin, Jews Against Prejudice, 135-43; "Role of JCR Agencies in Combatting Communism," folder 9, box 51, NJCRAC-AJHS. For an overview of the history of the postwar red scare, see Ellen Schrecker, Many Are the Crimes: McCarthyism in America (Princeton, NJ, 1998).
} 
in charge of production at MGM, and arguably one of the most powerful film producers of the 1950s. Schary had helped to organize the Los Angeles chapter of the Anti-Defamation League in the 1930s, and would serve as the national organization's chairman in the 1960s. A selfproclaimed dyed-in-the-wool "liberal," and perhaps the single figure most associated with Hollywood's "social message pictures," Schary faced interrogation by the House Committee on Un-American Activities (HUAC) in 1947 and attacks throughout the subsequent Hollywood blacklist era for his associations with left-liberal organizations. So concerned by the charges levied against him by figures such as conservative gossip columnist Hedda Hopper and the antisemitic, anti-communist Myron Fagan, he sought the FBI's protection. ${ }^{29}$

Martin Gang, another prominent member of the LA-CRC Motion Picture Committee, had helped found the Los Angeles chapter of the American Jewish Committee. Gang and Schary had both been members of the Hollywood Independent Citizens' Committee of the Arts, Sciences and Professions (HICCASP), a left-liberal organization under considerable communist influence. Dore Schary had served in its executive leadership in 1945 and 1946, although he was likely never a member of the Communist Party himself. After the blacklist began in 1947, Gang became known as the lawyer to see for those under attack by HUAC, and he represented or advised dozens of film industry workers. ${ }^{30}$

HICCASP had been at the vanguard of the industry's leftist politics; its 1945 constitution had demanded "international security," "full employment," "extension of the franchise and abolition of the poll tax," and "an end to racial discrimination and a permanent [Fair Employment Practices Committee (FEPC)]." And as one of HICCASP's leading members, Schary had co-edited a biting critique of Mississippi congressman John Rankin (D-MI), HUAC's most zealous, most racist, and most antisemitic anti-communist. Asserting that Jews and African Americans headed up a plot to make America communist, Rankin upheld segregation and stood fast against voting rights. For HICCASP and its members, HUAC's 1947 hearings and subsequent industry blacklists served as evidence for a domestic fascist threat. $^{31}$

The presence of Gang and Schary made it likely that the politics of the blacklist hung in the air of the LA-CRC's offices, even though both Gang and Schary had distanced themselves from HICCASP's politics by 1947. And there is no evidence that Stone was ever left of liberal. But Stone did express sympathy with more progressive goals in 1950 when he encouraged the producers of the race relations film The Well to include a message about employment. "A little of the old F.E.P.C. at any rate," he suggested to the producers, as he wrote in his report to the NCRAC. Despite this rare bit of commentary, Stone, Schary, and Gang were more likely to draw from a liberal individualist language when talking about race-one that that was gaining widespread currency among the members of Jewish liberal organizations as well as many others. $^{32}$

After World War II, racial liberalism took shape around the arguments of one singularly important text: sociologist Gunnar Myrdal's 1944 study An American Dilemma. Myrdal had

\footnotetext{
29"Blue Skies," Time, Feb. 21, 1949, 104; Dore Schary, "Executive Responsibility: A Case History," Films in Review 5, no. 7 (Aug.-Sept. 1954): 326; Hedda Hopper, "He Should Know," May 8, 1954, folder 12, box 99, Dore Schary Papers, Wisconsin Historical Society, Madison, WI [hereafter DS-WHS]; SAC Los Angeles to Director FBI, Jan. 2, 1951, Dore Schary File, Federal Bureau of Investigation, Washington, D.C. [hereafter DS-FBI]; SAC Los Angeles to Director FBI, Oct. 13, 1951, DS-FBI; Letter to Louis Nichols, Oct. 29, 1951, DS-FBI.

${ }^{30}$ Ceplair and Englund, Inquisition in Hollywood, 390-1; "Martin Gang; Lawyer in McCarthy Era," Los Angeles Times, Feb. 4, 1998, http://articles.latimes.com/1998/feb/04/news/mn-15451; M.A. Jones to Mr. Nichols, Oct. 29, 1951, 10, DS-FBI.

31 "Program on the Independent Citizens Committee of the Arts, Sciences and Professions," folder 20, box 4, HDC-WHS; "Introducing ... Representative John Rankin," box 7 folder 16, HDC-WHS; Edgar Peterson to Frank Capra, Nov. 30, 1945, box 101 folder 2, DS-WHS.

${ }^{32}$ John Stone, Report \#23, October 20, 1950, folder 6, box 43, NJCRAC-AJHS; Ceplair and Englund, Inquisition in Hollywood, 390-1.
} 
concluded that liberalism already contained the seeds from which racial equality might grow: an "American creed" of freedom and democracy. Racial liberalism presumed that if American egalitarianism was activated in individual whites by stimulating their wills, the problem of inequality would be solved. Not everyone agreed with Myrdal, of course. Ralph Ellison, for example, took issue with Myrdal's emphasis on reforming white consciousness, responding that "what is needed is not an exchange of pathologies, but a change of the basis of society."33

But Myrdal's idealistic vision undergirded Jewish intergroup relations organizations. Dore Schary declared Myrdal's work as monumental, second only to Uncle Tom's Cabin. And Schary's own 1949 film Intruder in the Dust, one of a number of popular major studio movies about "race relations" that year, served as a model for promoting racial liberalism in Hollywood. $^{34}$ Eschewing stereotypes of "coons" and "toms," Intruder in the Dust portrays its African American protagonist Lucas Beauchamp as a hard working, solemn, stoic landowner a self-sufficient man who has no need for help or assistance, who refuses to bow to the white men in town and insists that they call him "mister." Justly praised for its criticism of the deference culture of the South, the film nevertheless located solutions to the problems of inequality in the primacy of individual will and the need to reform individual hearts. Stone and the LA-CRC Motion Picture Committee heartily approved of Schary's movie as well as several other race relations films released that year, such as Home of the Brave, Los Boundaries, and the critically lauded Pinky. Films like these earned plaudits from Stone and liberal Jewish organizations because they did just the right kind of work: they promoted social tolerance while avoiding arguments for societal change, and they skirted the most contentious political issues of labor and anti-communism. They also featured no Jews. ${ }^{35}$

In March 1949 Stone expressed concern over an anti-communist film from Republic Pictures called Fathoms Deep. Eventually released that year as The Red Menace, it stands today as perhaps the most remarkable anti-communist film of the early Cold War. Relatively successful for a B-picture, The Red Menace was notable not only for its bludgeoning anti-communism, but also for its racial liberalism. The communist villains are incredibly clunky and cartoonish, but the racial politics of the film adhere carefully to the liberal humanism of the era. The Red Menace rejects the antisemitism and white supremacy of vicious anti-communists such as John Rankin. Celebrating assimilation and affirming the individual dignity of hard-working, patriotic African Americans and ethnic minorities instead, the film insists that it was communists, in fact, who dwelled too much on the matters of race, ethnicity, and Jewishness (Figure 1). ${ }^{36}$

At the start of the story, an Irish Catholic, an African American, and a Jew all belong to the American Communist Party; by the end, they have come to realize its evils. As the characters move from radical to liberal, the film consistently suggests that not only is it best to ignore difference, but also that this is the American way. For example, when Father Leary intervenes with the Irish American Molly, convincing her to leave the party, he does so by examining the language on American currency. On one side of the coin, the priest notes, are the words

\footnotetext{
${ }^{33}$ Ralph Ellison, “An American Dilemma: A Review," in The Collected Essays of Ralph Ellison, ed. John F. Callahan (New York, 2003), 328-40, here 340. For more on racial liberalism, see Jodi Melamed, who describes it as an "antiracism" based on "abstract equality, individual rights, and market liberties." Jodi Melamed, Represent and Destroy: Rationalizing Violence in the New Racial Capitalism (Minneapolis, MN, 2011), 20.

${ }^{34}$ Svonkin, Jews Against Prejudice, 197n16; "Weight of Evidence," Daytona Beach Morning Journal, June 1, 1968, $10 \mathrm{~B}$.

${ }^{35}$ John Stone, Report \#16, Dec. 29, 1949, folder 5, box 43, NJCRAC-AJHS; Minutes of the Meeting of the Motion Picture and Mass Media Committee, Oct. 6, 1949, folder 2, box 40, NJCRAC-AJHS; John Stone, Report \#13, Aug. 17, 1949, folder 5, box 43, NJCRAC-AJHS.

${ }^{36}$ Sbardellati, J. Edgar Hoover Goes to the Movies, 181.
} 


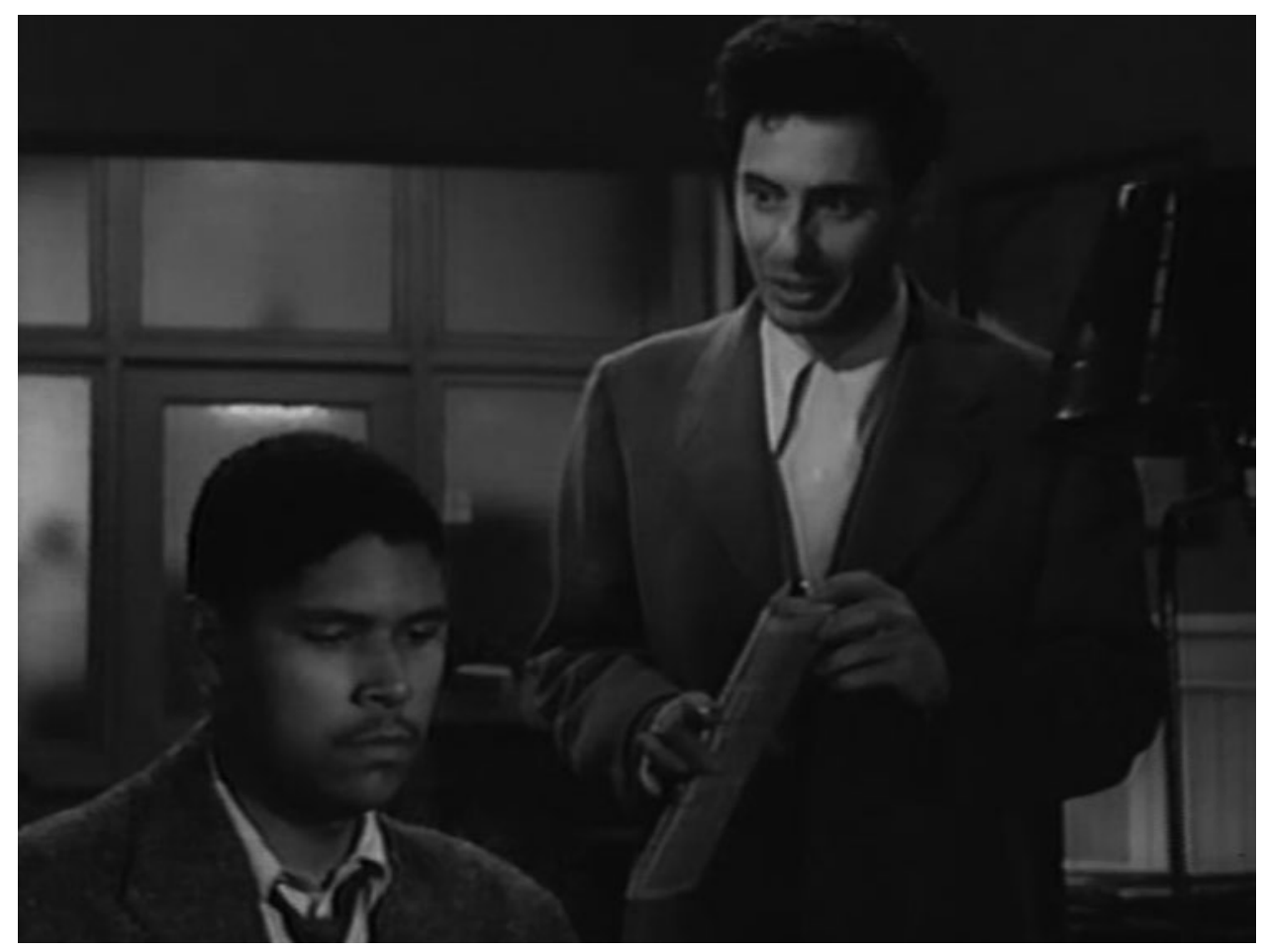

Figure 1. Henry Solomon (right) speaking to his friend Sam. Solomon has just told off his Communist Party superiors for, among other reasons, placing too much emphasis on racial issues and insisting that he is a "Jewish-American" and not simply an American. The Red Menace, dir. R. G. Springsteen (Republic Pictures, 1949).

"E pluribus unum." "We're not Irish, or English, or Jewish, or Russian," he explains, but American. He turns the coin over, reading "In God We Trust," arguing that atheism fosters hatred. He then equates the "class hatred" of communism with the "race hatred" of Nazism, suggesting that they are both the result of godless ways of thinking. ${ }^{37}$

Jewish organizations applauded this kind of racial liberalism, and yet Stone worried about the way the Jewish character might be understood. In response to studio assurances that The Red Menace merely showcased the characters coming together as Americans to denounce communism, Stone replied that the situation for Jews was unique. It was one thing for an Irish American to be shown as transforming from a communist to an anti-communist, Stone argued, but "the anti-Semitic canards that have been dinned into everybody's ears that Jew and Communist were synonymous" meant that "in trying to give the Jew a clean bill of health he may really be putting the Jews on the defensive and bearing out what the rabble rousers were proclaiming." This argument had little logic, but it echoed the broader critique of advocates like Silberberg who were reluctant to see any Jews on the screen at all, in message pictures or any others. ${ }^{38}$ Only after seeing the finished film did Stone decide that "the Catholic, Jew, and Negro are handled with dignity and consideration." 39

Stone wished for the movie studios to produce Jewish characters, fully realized Jewish characters, but cleanly separated from the tumultuous politics of the period. With high hopes, he reported on the development of MGM's movie about Oliver Wendell Holmes's The Magnificent Yankee (1950), which initially featured a prominently Jewish Louis Brandeis. But in the final cut, the

\footnotetext{
${ }^{37}$ The Red Menace, dir. R. G. Springsteen (Republic Pictures, 1949).

${ }^{38}$ John Stone, Report \#8, Mar. 4, 1949, folder 5, box 43, NJCRAC-AJHS.

${ }^{39}$ Stone, Report \#10, NJCRAC-AJHS.
} 
jurist's Jewishness was relegated to one throwaway line. A production about Harry Houdini, which Stone anticipated would emphasize the famous illusionist's Jewish background, proved even more disappointing. In the completed picture, those roots received no mention. ${ }^{40}$

Communist politics, too, remained a perennial headache. Stone dismissed an attempt to make a story about the Scottsboro Boys as towing the "commie line," an obvious statement perhaps, given that the Communist Party (CPUSA) helped to defend the wrongly accused African Americans. Of particular concern to Stone may have been that the CPUSA hired a New York Jewish lawyer to lead the defense in the famous 1930s trial. Such apprehension appears also to have driven Stone to dismiss an independent producer's attempts to make a film adaptation of the 1940 Richard Wright novel, Native Son. Wright's story features a noble Jewish Communist party lawyer, one of the few characters in the story to understand the tragic historical and sociological context in which the protagonist, an African American criminal, exists. Stone wrote the project off as radical and dangerous. ${ }^{41}$

Warner Brothers' successful 1951 anti-communist film, I Was a Communist for the FBI, similarly drove Stone to concern even though no Jews featured in it. Based loosely on the real life story of FBI agent Matt Cvetic, the film follows an agent who goes undercover in a Pittsburgh communist "cell." Like The Red Menace, it depicted a post-racial, assimilationist American society under threat by communists who sought to "divide" the country by sowing racial discontent. In one scene, members of the Communist Party admit to having started the 1943 race riots in Detroit and New York. In another scene, communist thugs foment a wildcat strike and then attack the noncommunist union members who opposed it with lead pipes wrapped in Yiddish language newspapers. Good workers, good Jews, and good African Americans are all betrayed by the antics of the Communist Party, which seeks to exploit minorities for its own purposes.

After screening the film, a furious Stone informed the NCRAC, which in turn sent a letter to Warner Brothers, objecting to the conflation of Communist tactics with any ethnic or racial identity:

The scene which shows the Communists wrapping lead-pipes in Yiddish papers may be misunderstood by many movie-goers. While undoubtedly your intentions in this scene were to depict Communist tactics, a identification between Jew and Communist may be created in some minds. The scenes revolving about the wildcat strike may give the impression that all labor strikes are maneuvered by the Communists. It is well known that the trade unions are among the chief opponents of Communism. Since nothing is said in the picture to the contrary, the inference could be also drawn from the scene depicting the meeting for Negroes, that all meetings in behalf of fostering better race relations are Communist inspired and that racial minorities are peculiarly susceptible to Communism.... ${ }^{42}$

The letter concluded that communism "cannot be dealt with, particularly in an entertainment media such as motion picture films, in a manner that does not sharply distinguish between Communism and genuine liberalism."

Stone also appears to have been personally aggrieved that Warner Brothers did not give him an advance copy of the script. After some back and forth, however, he reported that the incident ultimately resulted in better relations with the studio. He also softened his tone somewhat, reporting that after seeing I Was a Communist for the FBI with both a Jewish audience and a

\footnotetext{
${ }^{40} J o h n$ Stone, Report \#17, Jan. 13, 1950, folder 5, box 43, NJCRAC-AJHS; John Stone, Report \#22, Oct. 6, 1950, folder 6, box 43, NJCRAC-AJHS; John Stone, Report \#40, Jan. 7, 1952, folder 7, box 43, NJCRAC-AJHS.

${ }^{41}$ John Stone, Report \#34, Aug. 27, 1951, folder 6, box 43, NJCRAC-AJHS.

${ }^{42}$ NCRAC to Jack Warner, undated, folder 3, box 44, NJCRAC-AJHS.
} 
black one, it seemed as though viewers were responding "appropriately." But he continued to grumble about the film the following year, referring to the scene with Yiddish newspapers as "dangerous" and "inept." Between The Red Menace, I Was a Communist for the FBI, and attempts to produce films depicting Jews on the left, Stone and the NCRAC could only express frustration over the "great dearth" of what they conceived as "positive Jewish themes" such as "Chanukah." 43

Even depictions of Jews as working-class immigrants without any references to communism proved controversial among Stone and his colleagues in the LA-CRC Motion Picture Committee. For example, the group split over Paramount Studios' plans to put The Goldbergs, a popular radio-turned-television show starring a clearly Jewish New York family, on the big screen. In an October 1949 meeting, one committee member objected that The Goldbergs represented "the perfect example of stereotyping and is all the more dangerous because of its great popularity." But another countered that there was a difference between stereotyping Jews as "avaricious, unusually shrewd or engaging in unethical practices" and portraying them, like Gertrude Berg, the show's creator and star did, as "warm friendly people."

The Communist West Coast publication, the Daily People's World, had its own opinion of Paramount's news, arguing that the TV show's characters may have been "warm" and "sympathetic," and compelling subjects for the big screen. But unfortunately, the newspaper argued, "Paramount has not the will to portray the real problems of the Jewish people in America on the screen-and 'the Goldbergs' is destined to rely for its drama on trivia, and for its humor on accents, malapropoisms, and stereotypes.... The danger is that the Jewish people will be held up to ridicule." 45 The predictions of the Daily People's World so concerned Stone that he took them directly to Paramount. The studio assured him that the Goldbergs "will be represented as an American family that mingles with other families that make up the American pattern of democracy. There will be no reference to their Jewishness, or Catholicism-or any other creed." In this case, Stone, the LA-CRC, and the Communists all concurred. It was best, they concluded, not to put Jewishness on screen, at least when it came to the Ashkenazi working class. ${ }^{46}$

If Stone found Gertrude Berg's matriarch Molly Goldberg controversial, Budd Schulberg's Sammy Glick was decidedly detestable. Schulberg's novel, What Makes Sammy Run? (1941), formed part of a rich literary tradition in which Jewish American writers expressed concerns about assimilation and capitalist values through immigrant Jewish characters who sought to rise out of poverty and onto "Allrightnik Row," often by making moral compromises that damaged friends and family. Stone feared that Schulberg's story, ripe for cinematic reinterpretation, was antisemitic, and he said as much to the author's father, B. P. Schulberg, in 1949. The elder Schulberg, a Hollywood producer, ensured Stone that any film adaptation of the novel would balance the eponymous avaricious immigrant Sammy Glick with positive Jewish characters. But three years later, Stone expressed dismay over the "obnoxious character of Semitic ancestry" exhibited by a planned television version. ${ }^{47}$

\footnotetext{
${ }^{43}$ Ibid; John Stone, Report \#30, May 4, 1951, folder 6, box 43, NJCRAC-AJHS; John Stone, Report \#41, Feb. 25, 1952, folder 7, box 43, NJCRAC-AJHS; John Stone, Report \#43, Apr. 1, 1952, folder 7, box 43, NJCRAC-AJHS; "Excerpt from NCRAC 1953 Joint Program Plan - Recommendation in Area of Mass Media," undated, folder 5, box 44 , NJCRAC-AJHS.

${ }^{44}$ Minutes of the Meeting of the Motion Picture and Mass Media Committee, Oct. 6, 1949, folder 2, box 40, NJCRAC-AJHS.

${ }^{45}$ John Stone, Report \#20, May 10, 1950, folder 6, box 43, NJCRAC-AJHS.

${ }^{46}$ Stone, Report \#20, NJCRAC-AJHS. For more on The Goldbergs and the politics of ethno-religious representation, see George Lipsitz, "The Meaning of Memory: Family, Class, and Ethnicity in Early Network Television," in Time Passages: Collective Memory and American Popular Culture (Minneapolis, MN, 1990), 39-75.

${ }^{47}$ Stone, Report \#13, NJCRAC-AJHS; John Stone, Report \#39, Jan. 17, 1952, folder 6, box 43, NJCRAC-AJHS.
} 
In the early 1950s, it appeared that no major studio wanted to make films that dwelled on the complexities of ethnic identification, class inequality, and other themes that had distinguished films of the 1940s such as Gentleman's Agreement and Body and Soul. By 1952, the American Jewish Committee's influential journal Commentary was lamenting "the Vanishing Jew of Our Popular Culture." Stone and the NCRAC occasionally looked back fondly on the positive film portrayals of Jews in 1946 and 1947. But, ironically, they had also resisted efforts to make more pictures like them. Perhaps the "almost complete disappearance of the Jew" from popular arts and media was caused not simply by studio producers' cold feet, but also by trepidation on the part of John Stone, the NCRAC, and the LA-CRC. ${ }^{48}$

Enter biblical epics. The genre dominated 1950s Hollywood. Samson and Delilah topped the box office in 1950, and the next year, David and Bathsheba did the same. Quo Vadis placed second highest earner for 1952, and The Robe took the number one spot the year after that. The era's greatest biblical epic successes were yet to come: in 1957, The Ten Commandments grossed more than any other movie, and in 1960, Ben-Hur did too. ${ }^{49}$

Stone, who had been so troubled by the genre when he stepped into his position, soon discovered that biblical films made reliable vehicles for portraying positive Jewish characters, but ones conveniently devoid of their contemporary social contexts and recent history. In short, they featured no immigrants, no communists, and no union members. Biblical epics of the 1950s, moreover, hewed to the liberal humanist messages that Stone and others found attractive. The films' liberalism bore no connection to civil rights or economic justice or the modern institutions that might bestow them. Instead they championed a kind of neo-classical conception of liberty.

From one perspective, biblical films were not about religion at all. Instead, they helped Americans explore the question of what it meant to live in a "free world." Biblical epics celebrated the primacy of the individual by consistently pitting their protagonists against colonizing forces, and they contrasted their heroes' agency as individuals with the lack of freedom experienced by slaves. But they also distinguished between liberalism and libertinism, underscoring the importance of individual moral duty and self-governance as bulwarks against both anarchy and autocracy. Individual will alone held the promise to resolve societal crises and imbalances of power.

Stone and other members of the LA-CRC lauded Samson and Delilah (1949), one of the first postwar examples of the genre, directed by the staunchly conservative Republican Cecil B. DeMille, who screened it personally for them. "The picture is magnificent," Stone reported to the NCRAC, declaring that "Samson is portrayed with the simple, dignity, clean strength, and unwavering faith in God that will be a lasting tribute to our people." Samson's Jewishness is elided in the film-he and his people are only described as "Danite," and no mention of Jews or Judaism is made. But Stone insisted that "he is Jewish in the eyes of everyone who has ever read or heard of the Old Testament." For Stone and the LA-CRC, Samson and Delilah hit the sweet spot. It gave tribute to Jewish people, but in just the right way. ${ }^{50}$

DeMille deliberately crafted his film to address the contemporary moment. His Samson represents the ideal mid-century humanist man whose strength lay in his individual body, and whose potential was maximized when his will remained unclouded by the influence of others. The Philistines are no match for Samson in battle, and so the film plays out as a contest against

\footnotetext{
${ }^{48}$ Jules Cohen to Sidney Vincent, May 9 1956, folder 4 box 40, NJCRAC-AJHS; Stone, Report \#4, NJCRAC-AJHS; Minutes of the meeting of the Mass Media Committee on Motion Pictures, New York City, May 24, 1948, folder 1 box 44, NJCRAC-AJHS; Henry Popkin, "The Vanishing Jew of Our Popular Culture," Commentary, July 1952, 46-55, here 46.

${ }^{49}$ Cobbett Steinberg, Reel Facts: The Movie Book of Records (New York, 1978), 338, 344-8.

50"Minutes of meeting of Mass Media Committee on Motion Pictures," Oct. 20 1948, folder 1, box 40; John Stone, report \#15, Oct. 24, 1949, folder 3, box 43, NJCRAC-AJHS.
} 
the subversion of his soul at the hands of Delilah, less a Biblical archetype than a onedimensional femme fatale foil for the male hero-a common convention in 1950s cinema. Training her eyes on Samson, Delilah tells a fellow Philistine, "sometimes a bee can move an ox," and she sets out to tempt him several times-sometimes out of passion, and other times out of spite. Because Samson already enjoys "drinking and dice throwing" with the libertine Philistines, she finds it easy to seduce him, thereby preventing him from meeting his destiny as, in the words of Samson's mother, the Jews' "chosen leader." Only at the end of the film does Samson reject temptation and selfishness, and realize his moral duty, allowing him to destroy the Philistine temple in which he has been incarcerated. ${ }^{51}$

DeMille also quite explicitly adopted the language of mid-century humanism in the film's prologue, the only sequence in which a narrator speaks directly to the audience:

Before the dawn of history, ever since the first man discovered his soul, he has fought against the forces that desired to enslave him. He saw the awful power of nature arrayed against him ... enslaving his mind in shackles of fear. Fear bred superstition, blinding his reason.... Human dignity perished on the altar of idolatry. And tyranny rose, grinding the human spirit beneath the conqueror's heel. But deep in man's heart, still burned the unquenchable will for freedom. ${ }^{52}$

Freedom here is classically liberal: an imagined state of nature that exists before history, and necessarily precedes all other social configurations. Fear, DeMille tells audiences, sends man running to form communities, which lead to states, which lead to tyranny. And so the solution for combatting such a progression and restoring "human dignity" is found in the will to rediscover freedom.

David and Bathsheba (1951) followed quickly after the success of Samson and Delilah, and similarly offered no cause for concern at the LA-CRC. After one screening Stone reported that "a number of rabbis" found the film "boring," but added that it was doing "remarkable business." Curiously, he noted: "There has been no anti-Semitic reaction or even any indication that the modern Jews are in any way identified with the ancient people portrayed in the film." In the case of Samson and Delilah, Stone was quick to suggest that contemporary audiences would understand DeMille's film as having "modern implication in the victory of Jewish faith which brought about the rise of the State of Israel, after the fall of powerful Germany." But in the case of David and Bathsheba-which was a bedroom melodrama as much as it was a biblical epic-Stone decided to downplay its relevance. ${ }^{53}$

Following David and Bathsheba's "phenomenal success," Stone noticed that studios began to feverishly register all kinds of biblical film names with the Motion Picture Association, and even though the scare about antisemitic passion plays had abated, he remained wary of the significant portion of those titles that drew stories from the New Testament. "A script can start out by establishing that all the early Christians - the apostles, saints, etc.--were Jews, but the fact remains that they eventually turned away from the Jewish faith," he lamented. "All these stories lead up to the Crucifixion no matter how 'favorably' they start." Wary about New Testamentinspired productions, such as 20th Century Fox's The Robe, he was instead bullish about the possibility of Old Testament epics, which might make "plenty of positive contributions to Jewish community relations." Not surprisingly, DeMille's The Ten Commandments excited Stone even more than Samson and Delilah had. ${ }^{54}$

\footnotetext{
${ }^{51}$ Samson and Delilah, dir. Cecil B. DeMille (Paramount Pictures, 1949).

${ }^{52}$ Ibid.

${ }^{53}$ Stone, Report \#34, NJCRAC-AJHS; Stone, Report \#15, NJCRAC-AJHS.

${ }^{54}$ John Stone, Report \#36, Oct. 24, 1951, folder 6, box 43, NJCRAC-AJHS; John Stone, Report \#58, Apr. 9, 1953, folder 8 , box 43 , NJCRAC-AJHS.
} 
In his reports about that film, Stone bragged that DeMille gave him a copy of the script before anyone else outside of the production crew, that DeMille discussed Stone's notes and suggestions days before filming, and even consulted Stone on such details as what a shofar sounded like. Stone happily connected DeMille with the "best man" that the Union of American Hebrew Congregations "could find," and reported that DeMille was "surprised" by how "unimpressive" the horn was, but assured his NCRAC readers that "stereophonic and amplified sound [would] no doubt make the shofar blasts crash over mountains and crags." Stone had an even more significant impact on the film by advocating the deletion of a line of dialogue where angry Jews, distrustful that Moses can lead them out of Egypt, shout "crucify him!" Stone noted the problematic reference, and DeMille struck the line. ${ }^{55}$

Stone was convinced that The Ten Commandments would "have the greatest positive impact for the Jews." It would teach audiences that "the great humanitarian principles, including the Ten Commandments, were given to the world by the Jews." After seeing the finished film, he gushed that it would "engender pride in our heritage in the hearts of those of us who never learned its meaning." The purpose of the film, he declared, was to "remind the world that it was the Jews who gave it the Law, and basis of today's civilization with its great concept of human freedoms." The Ten Commandments allowed Jews to enter the national discourse not as immigrants, workers, or radicals, but as the progenitors of liberal Anglo-Saxon tradition. Such a portrayal accomplished precisely what the policy vision of liberal Jewish organizations during the Cold War called for: a championing of liberal institutions that would simultaneously defend Jewish interests while downplaying Jewish difference. ${ }^{56}$

More than a retelling of Judeo-Christian mythology, DeMille's The Ten Commandments offered instruction for liberal democratic society. The "rule of law" stands as the central theme of the film, introduced in an onscreen appearance by DeMille himself. Narration reinforces the theme throughout the retelling of Moses's quest to free the Hebrew people from slavery in Egypt. And Moses himself, played by Charlton Heston, voices what is presumably God's wish, that "man should be ruled by law and not by the will of other men."57

Law, in DeMille's estimation, worked as double-sided currency. On one face of it, law provided the means by which people liberated themselves from bondage. When the director appears on screen, he announces that this is the story of the "birth of freedom," and the film suggests that the "rule of law" is the midwife. In one scene, Moses declares to the pharaoh, "man shall be ruled by law and not by the will of other men." Governed by a totalitarian ruler, the Egypt of the film undoubtedly raises comparisons with contemporary communist regimes, but certainly legal institutions and autocracies are not mutually exclusive. DeMille is using the "rule of law" as a particular kind of shorthand. A modern liberal state, he suggests, is the antithesis to cruel dictatorships that deny their subjects individual autonomy. ${ }^{58}$

Notably, the other face of DeMille's "law" is meant to act as a check on that very autonomy. As Joseph Haker argues, DeMille sought to imagine and articulate a code by which individuals in a liberal society would adopt "conduct" befitting of free people in a consumer market society. The dénouement of the film comes when the Hebrew people, having left Egypt, revel in their freedom by worshipping false idols and embracing "sin" and libertinism. Their behavior contrasts with that prescribed by the tablets that Moses has just received from God. Their failure to act as God intended them to is not a failure of their leader, Moses, or of their state, which they have rightly rejected, but rather a failure of their own individual self-governance. Law is not something to be regulated and institutionalized, but instead internalized. The story thus fit

\footnotetext{
${ }^{55}$ John Stone, Report \#69, Apr. 8, 1954, folder 8, box 43, NJCRAC-AJHS; John Stone, Report \#75, Oct. 1, 1954, folder 8 , box 43 , NJCRAC-AJHS.

${ }^{56}$ Stone, Report \#75, NJCRAC-AJHS; John Stone, Report \#95, Aug. 7, 1956, folder 10, box 43, NJCRAC-AJHS.

${ }^{57}$ The Ten Commandments, dir. Cecil B. Demille (Paramount Pictures, 1956).

${ }^{58}$ Ibid.
} 
tidily with ascendant postwar narratives about the individual as a rational actor who, if properly cultivated, would save mankind from the threat of imperious states. The Ten Commandments retold a story central to the Jewish faith, but the values of Moses's Egypt were wildly different than those of Paul Robeson concertgoers back in Peekskill, New York. If Popular Front music, film, and stories such as Native Son followed the underclass and minorities, and explored how society might orient itself towards them, The Ten Commandments instead showcased individuals behaving as individuals, and conducting themselves autonomously. ${ }^{59}$

It made perfect sense that the liberal Jews of Hollywood would back Old Testament stories such as Samson and Delilah and The Ten Commandments. Yet at the same time Stone continued to worry about New Testament films. When The Robe appeared on 20th Century Fox's production list, he lamented the production of more films that might dwell on the crucifixion of Jesus and in doing so, suggest that Jews were complicit. After reviewing advance scripts and speaking with the producer of the movie, however, he became confident that the crucifixion scene posed little problem; it appeared early in the film, and "mostly by symbolism," as he put it. After screenng a portion of the film he reported that it presented "no problem to the Jewish community," and that the "Cinemascope" and "Technicolor" were "quite stunning."60

After The Robe was released in the fall 1953, Stone "arranged for groups of rabbis of the three wings" to see the film and reported that "all of them expressed their pleasure" that Jews were not depicted as being involved in the persecution of Jesus and his followers. Stone brought the rabbis in not only to allay their fears but also, it seems, to encourage film attendance among their congregations. "The studio reports that Jewish patronage increased substantially since these parties were inaugurated," he wrote in one report. ${ }^{61}$

It seems unlikely that Stone would have brought the rabbis to see a film about Jesus just so that they might spread the good word. But when another big budget historical epic about the period following Jesus's death, The Silver Chalice (1954), came out a year later, Stone advocated for that one as well, once again pushing aside fears that the film might be antisemitic by stressing his role in vetting the script and touting the film's "positive Jewish values." But other features made it appealing too. Like Quo Vadis, The Robe, and The Ten Commandments, The Silver Chalice concerns man's quest for individual freedom in the context of slave-owning societies, and highlights the responsibility demanded in exercising such freedom. ${ }^{62}$

The Silver Chalice is a Christian film in no uncertain terms; the protagonist, a talented sculptor played by Paul Newman, is a protector of the Holy Grail, charged with adorning it with engravings of Jesus and his disciples. Meanwhile, Romans set out to steal the grail and break the Christian resistance to Rome. More than merely stamp the film with his seal of approval, Stone insisted that "the Jewish community" should "indicate its appreciation" for The Silver Chalice. He worried that if Jews failed to see epics about Jesus, relations with the studios would deteriorate. "The failure to compliment 20th Century-Fox on its contributions to good human relations in 'The Robe' was keenly felt at the studio," reported Stone. "The general feeling among studio personnel is that our community doesn't hesitate to flood them with protests, but is strangely silent on other other occasions." Significantly, Stone never admonished his readers for not supporting other films-ones about racial tolerance or wholesome family dramas or comedies. ${ }^{63}$

In early 1955, Stone was still extolling the virtues of The Robe and the need for Jewish audiences to see it. When he received word that the Israeli government had approved the movie for exhibition, he remarked that this "should mean something to many of our community who

\footnotetext{
${ }^{59}$ Joseph Haker, "Moses and the Marketplace," in A Destiny of Choice? New Directions in American Consumer History, eds. David Blanke and David Steigerwald (Lanham, MD, 2013), 135-153.

${ }^{60}$ John Stone, Report \#50, Sept. 15, 1952, folder 7, box 43, NJCRAC-AJHS; Stone, Report \#58, NJCRAC-AJHS.

${ }^{61}$ John Stone, Report \#64, Nov. 2, 1953, folder 8, box 43, NJCRAC-AJHS.

${ }^{62}$ John Stone, Report \#70, Apr. 30, 1954, folder 8, box 43, NJCRAC-AJHS.

${ }^{63}$ Stone, Report \#70, NJCRAC-AJHS.
} 
refuse to see the picture 'on principle' even though it is as clean of 'Jewish guilt' as any Christological film can possibly be.” In other words, Stone was taking shots at Jews for not wanting to see a movie about Jesus. He also reported that The Robe was now playing and breaking records in Paris, where, he argued, it helped to "dispel the myth of 'Jewish guilt" abroad. Apparently, New Testament epics promised more than the presentation of positive images of Jews, as the Motion Picture Project first set out to encourage; these films could also prevent negative images by spurring the creation of myths where Jews receded or disappeared altogether. Here, Stone's strategy to celebrate Hollywood's new stories about Jesus paralleled the liberal Jewish organizations' decisions to de-emphasize difference and privilege classically liberal conceptions of freedom-what Stone presumably had agreed were "Jewish values."

Such values flowed abundantly in Ben-Hur (1959). The original Lew Wallace novel Ben-Hur: A Tale of the Christ (1880) had been the best seller of the nineteenth century. Its popularity, as Heather Cox Richardson suggests, may have owed to its focus on an individual's struggle against "government persecution" and its conjuring of a "free labor vision," celebrating "the power of a single individual" and emphasizing "middle-class morality." 65 Still, Stone had concerns about the MGM movie adaptation, particularly with the final part of the movie, which dealt with "early Christianity." But the film's Jewish director William Wyler proved receptive when Stone suggested to the studio that it make multiple changes to the script. Stone reported that Wyler called him to say that he was "grateful" for Stone's comments and that Wyler had made "all of the recommendations" that Stone had offered. ${ }^{66}$

The final version of the film, which centered on a Jew's ability to maintain faith through hardships, earned Stone's wholehearted recommendation. "Quite a number of my suggestions were incorporated," he reported, including details such as Ben-Hur's kissing of a mezuzah. Stone thought the crucifixion scene too graphic, but was happy that no Jews were involved in the crime-only Romans-and more importantly, "nobody actually turns Christian" in the film. His zeal for Ben-Hur grew even greater as it earned critical acclaim and box office success. When it won eleven Academy Awards, Stone declared it "the greatest Jewish document in the history of the cinema," and added that he was "happy that [he] was given the privilege of making an important contribution to it." ${ }^{\prime \prime}$

Ben-Hur follows one man's efforts to achieve liberation against two combined forces: internal temptation and outward oppression. Judah Ben-Hur is Jewish royalty, accustomed to some amount of privilege and power, even as his land is subject to Rome's empire. Enslaved for a time for challenging Roman rule, Ben-Hur seeks revenge against Messala, the Roman tribune (and once childhood friend) who had him imprisoned. But after Ben-Hur kills Messala, he faces a greater challenge: an invitation to join the rulers in Rome. Through an unlikely series of events during his previous adventures as a prisoner in a Roman galley, Ben-Hur had come to earn the respect of Arrius, a powerful Roman consul. This consul, Pontius Pilate tells Ben-Hur, has offered him Roman citizenship. "Perfect freedom has no existence," Pilate advises, and so the wishes and desires of the Jewish people for liberation are quixotic. Ben-Hur's temptation to join Rome is one that can only be combatted effectively with the assertion of an autonomous will. "I am Judah Ben-Hur," the hero responds-a declaration not of his ethno-religious identity, but of his liberal individual self (Figure 2). ${ }^{68}$

\footnotetext{
${ }^{64}$ John Stone, Report \#79, Feb. 21, 1955, folder 9, box 43, NJCRAC-AJHS. John Stone, Report \#78, Jan. 18, 1955, folder 9, box 43, NJCRAC-AJHS; Stone, Report \#70, NJCRAC-AJHS.

${ }^{65}$ Melani McAlister, Epic Encounters: Culture, Media, and U.S. Interests in the Middle East since 1945 (Berkeley, CA, 2005), 18, 19; L. Ashley Squires, "The Wealthiest Man in the Empire: Ben-Hur as Model of Evangelical Political Engagement," Arizona Quarterly 69, no. 1 (Spring 2013): 23-46, here 23; Heather Cox Richardson, West from Appomattox: The Reconstruction of America after the Civil War (New Haven, CT, 2007), 190.

${ }^{66}$ John Stone, Report \#114, May 27, 1958, folder 11, box 43, NJCRAC-AJHS.

${ }^{67}$ John Stone, Report \#127, Nov. 2, 1959, folder 11, box 43, NJCRAC-AJHS; Stone, Report \#133, NJCRAC-AJHS.

${ }^{68}$ Ben-Hur, dir. William Wyler (Metro-Goldwyn-Mayer, 1959).
} 


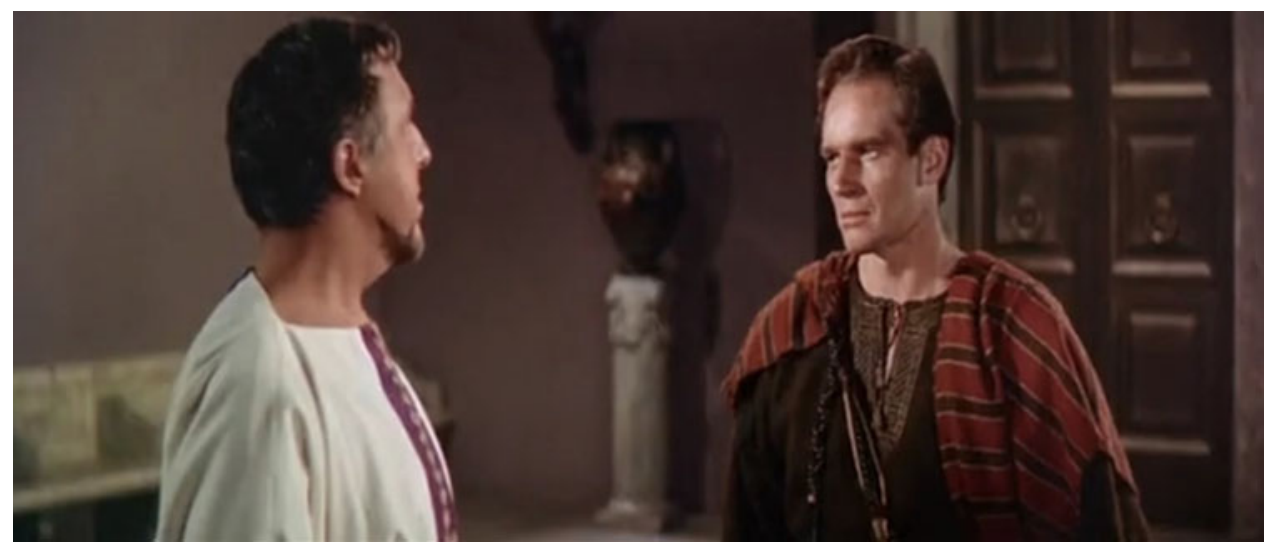

Figure 2. Pontius Pilate (left) tells Judah Ben-Hur that "perfect freedom has no existence," but Ben-Hur rejects such a notion. Ben-Hur, dir. William Wyler (Metro-Goldwyn-Mayer, 1959).

Ben-Hur tells the Roman Pontius Pilate how his mother and sister became lepers after spending four years in a Roman dungeon. He explains to Pilate that "the cruelty of Rome" spreads in the blood of his family, just as it also transformed his childhood friend, Messala, into his enemy. For Ben-Hur, the imperious state of Rome had infiltrated the bodies of those closest to him. In his conception of the liberal self, perfect freedom does exist, but only apart from state institutions. These are threats in Ben-Hur, like diseases, both literal and metaphorical, that infect individual bodies. ${ }^{69}$

Curiously, Jesus appears throughout the film, but never as part of any freedom movement. Only in the narration at the start of the film does a voice proclaim that "a redeemer" would bring "freedom" to the Jewish people. During Jesus's crucifixion at the movie's climax, Balthazar remarks that Jesus is being killed for taking on the burden of man's sins, but no one mentions that Jesus was opposing Roman rule. And neither is there any mention of Jesus's teachings about charity. The interweaving of Jesus's story with that of Ben-Hur's only appears to suggest that Jesus's message of love, relayed to Ben-Hur through Balthazar and Esther, allows Ben-Hur to realize his fully rational self, to overcome the temptations of revenge and powerlust, but not necessarily to fight for a better world. In a miraculous epilogue to the crucifixion, Ben-Hur's sister and mother are cured of their leprosy, an effect of Jesus's death. But Judea is not freed from Roman rule. Ben-Hur simply returns to his house-not to his community, but to his family.

Why did the man chosen by the major American Jewish organizations to represent them in Hollywood bestow the title of "the greatest Jewish document in history" on a movie subtitled "A Tale of the Christ"? Ben-Hur featured a Jew as its protagonist. It depicted Jews as rooted in the land of their ancestors, not as itinerants or immigrants. It celebrated self-determinism and liberal freedom, while at the same time downplaying the radical politics of the Jews' attempted revolt against Rome. And it reaffirmed the importance of individual moral will over state governance or group identity.

In fact, the director of Ben-Hur, William Wyler, had likewise shifted from a political orientation predicated on group rights to one of personal freedoms in the decade prior to the release of the film. Wyler had been a member of Hollywood's wartime left-liberal organizations, active in the same anti-fascist circles as Martin Gang and Dore Schary. Wyler made a hard split with the radical members of HICCASP when the U.S. Congress announced its intentions to investigate the film industry in 1947, a year after Wyler's "social message" masterpiece, The Best Years of Our Lives, premiered. However, Wyler did help to organize and lead the Committee

\footnotetext{
${ }^{69}$ Ibid.
} 
for the First Amendment (CFA) while Congress held hearings that October. Wyler and other celebrities took to the radio airwaves across the country to denounce HUAC's methods even as the CFA distanced itself from anti-fascist politics. ${ }^{70}$

Very carefully, the CFA made sure not to concern itself with defending communists or "fellow travelers," or to advocate for progressive causes, but instead only charged HUAC with creating an atmosphere of fear. According to the CFA, HUAC was "guilty of a violation of the long established Anglo-Saxon-American principles of individual accountability." That Wyler and others would turn to the language of "Anglo-Saxon" principles is telling; in the past left-liberal groups such as HICCASP had consciously refuted such language. In fact, less than a halfcentury before, the phrase "Anglo-Saxon" would have been understood as having indisputably racist connotations. Ben-Hur, The Ten Commandments, and Samson and Delilah were not Semitic or Christian, but instead invested in these very same "Anglo-Saxon-American principles.” Therefore they could appeal to Jews, Christians, Cold War liberals, and conservatives alike. $^{71}$

In a 1950 meeting of the Screen Directors Guild, in a confrontation that became infamous in Hollywood history, Wyler nearly came to blows with the staunch conservative Cecile B. DeMille. The conflict erupted over DeMille's insistence that the guild's members take loyalty oaths to prove they were not communists, which Wyler, who was undoubtedly sympathetic to progressive causes, opposed. But the fact that both men soon created immensely popular and similarly liberal humanist epics is not proof that one side of Hollywood's cultural battle "won" or "lost." Rather it speaks to how postwar Hollywood's stories both influenced and nourished a new kind of liberal subjectivity and cultural common sense. ${ }^{72}$

In late 1956, at a meeting of clergy attended by Stone and the head of the PCA Geoffrey Shurlock, a Methodist bishop stood to respond to complaints that Hollywood movies such as The Ten Commandments played too loosely with the Bible. Extolling DeMille's film as one that showed that "human liberty is rooted in God," he stated: "I have no patience with those who insist on rigid literalism in interpretation of a Biblical story. Preachers don't follow that precept. They select a Bible text and then take off-wherever their imagination carries them." The bishop was articulating what is now a common observation in religions studies: that ideas, norms, and values are brought to religions texts, not extracted from them. the liberal imagination is what postwar Americans brought to the texts of the Bible, both New and Old Testament. $^{73}$

The history of the LA-CRC's and the Motion Picture Project's embrace of Hollywood biblical epics is perhaps an odd little story, particularly in contrast to the witty fiction posed by the Coen Brothers in Hail, Caesar! But it also offers a telling example of one of the many ways in which a particular kind of liberal humanism came to supplant Popular Front-era discourses that had paid much more attention to social relationships and structural inequalities. American Jews have always been socialist, liberal, conservative, libertarian, and all manner of

\footnotetext{
${ }^{70}$ William Wyler, letter draft, Mar. 9, 1956, folder 596, box 46, William Wyler Papers, Margaret Herrick Library, Los Angeles, CA (hereafter WW-MHL); "In Fact," manuscript, June 30, 1947, folder 598, box 46, WW-MHL; Kahn, Hollywood on Trial, 140-1; "Now Available on Records...," Nov. 28, 1947, folder 9, box 4, HDC-WHS; "HLYD FIGHTS BACK - (FINAL) - SPOT 27 LIVE," folder 596, box 46, WW-MHL; "Committee for the First Amendment," folder 596, box 46, WW-MHL; William Wyler to Bosley Crowther, Nov. 1947, folder 596, box 46, WW-MHL.

${ }^{71}$ Kahn, Hollywood on Trial, 143; "Writers' War Board Strongly Attacks Anglo-Saxon Myths," Hollywood Independent, Oct. 1945, 2, folder 17, box 4, HDC-WHS.

${ }^{72}$ Ceplair and Englund, The Inquisition in Hollywood, 369.

${ }^{73}$ John Stone Report \#99, Jan. 2, 1957, folder 10, box 43, NJCRAC-AJHS.
} 
persuasions in between. But the formation of a powerful postwar liberal bloc, troubled by the totalitarianism of Nazi Germany and the Stalinist Soviet Union, coerced and disciplined by anti-communist and anti-labor culture, wrestling with questions about whether there was anything exceptional about the American Jewish experience, and increasingly persuaded by racial liberalism and free market economic principles, contributed in visually powerful ways to a liberal humanist structure of feeling in American thought, arts, and culture. ${ }^{74}$

If Jews, like other liberals of the postwar period, were "against prejudice" as historians tell us, it is worth asking how they conceived of the tools to fight prejudice, and which tools they deemed to be too risky to wield. ${ }^{75}$ Even when attempting to combat discrimination, liberals privileged the "unmarked, universal man," an individual with no social context or subjectivity. ${ }^{76}$ And in so doing, they recirculated the myths and symbols of classical liberalism. Moses could lead the Jews out of Egypt, and Jesus could inspire personal transformations in Rome. But the promised land could have no planned economies or regulatory boards. The Motion Picture Project's embrace of the biblically inspired individual archetype reflected the same magical thinking behind the mid-century intellectuals' embrace of the unmarked, universal man-one buoyed by the privileges that postwar white and white ethnic communities enjoyed.

Stone's story not only complicates the history of mainstream Jewish civil rights advocacy in the 1950s, but it also challenges the assumption that the cultural forces of the era can be understood as existing on a simple continuum from progressive to conservative. Simultaneously modern and reactionary, liberal humanism carried the potential to satisfy both the civil libertarian left and the nascent libertarian right. In other words, when Jews adopted liberal humanist rhetoric, they took part in a common project: not simply making or ceding ground, but also re-orienting themselves on a discursive terrain that was shifting beneath their feet. Liberal humanism was the new high ground, while progressive civil rights, or "positive freedom," became a no-man's land. ${ }^{77}$

To describe a "consensus" of the postwar period is a fraught enterprise to be sure. Historians have warned us that to see the "liberal consensus" as anything more than an unfinished project is to buy into a whiggish interpretation of history. But if a consensus existed, perhaps it was not so much bound up in a particular approach to economics or foreign policy, but instead took shape around a general acceptance of the primacy of the idea of "liberties" over "rights." Historians have recently argued that contrary to accepted wisdom, the politics of the 1950s were more "liberal" than "conservative." But we should respond with more vigorous attempts to formulate a cultural genealogy of liberalism itself. What did liberalism mean in the 1950s? What forms of knowledge came out of liberalism? What symbols, stories, and norms did it produce ${ }^{78}$

\footnotetext{
${ }^{74}$ On exceptionalism, see Tony Michels, "Is American 'Different'? A Critique of Jewish American Exceptionalism," American Jewish History 96, no. 3 (Sept. 2010): 201-24.

${ }^{75}$ Svonkin, Jews Against Prejudice; Shana Bernstein, Bridges of Reform: Interracial Civil Rights Activism in Twentieth-Century Los Angeles (New York, 2011).

${ }^{76}$ Greif, The Age of the Crisis of Man, xi-xii.

${ }^{77}$ On the idea of positive freedom, see John Dewey and James H. Tufts, Ethics (New York: 1908), 437-9; and Charles Taylor, "What's Wrong with Negative Liberty," in Philosophy and the Human Sciences: Philosophical Papers 2 (New York: 1985), 211-29.

${ }^{78}$ Jennifer A. Delton, Rethinking the 1950s: How Anticommunism and the Cold War Made America Liberal (New York, 2013). For a history of the project of making an American consensus, see Wendy L. Wall, Inventing the "American Way": The Politics of Consensus from the New Deal to the Civil Rights Movement (New York, 2008). For the political economic history of the postwar period, also see Lizabeth Cohen, $A$ Consumers' Republic: The Politics of Mass Consumption in Postwar America (New York, 2003); Landon R. Y. Storrs, The Second Red Scare and the Unmaking of the New Deal Left (Princeton, NJ, 2012); and Kim Phillips-Fein, Invisible Hands: The Businessmen's Crusade Against the New Deal (New York, 2009).
} 
Just a month before Stone died in 1961 at the age of 72, the Los Angeles Times profiled him as an "unofficial guardian of brotherhood and religious tolerance in motion pictures." Quoting Stone, the paper reported that writers and producers "welcomed" his suggestions and "always [gave him] a hearing." Like Samson, perhaps Stone did have an unexpected amount of power. But if Delilah was right in declaring "sometimes a bee can move an ox," it is also important to ask what winds and currents moved the bee. After all, the Motion Picture Project's embrace of biblical epics may have been conceived of as serving "Jewish values," but its ideological tilt and concrete successes were ill-suited to the needs of the minority groups that Jewish secular organizations had pledged to serve. ${ }^{79}$

This interpretation runs against the grain of recent literature celebrating liberal religious pluralism and the Protestant, Catholic, and Jewish figures who advocated for it. What Kevin Schultz has identified as a "tri-faith America" grew from much more than the widening acceptance of the doctrine of liberal pluralism itself. ${ }^{80}$ In the case of John Stone, religious discourse was no empty vessel; it was a carrier for particular values and norms. The values that liberal Jews took to calling theirs allowed for Stone's alignment with the most popular of Hollywood's cultural products of the blacklist era. His hunt for the right stories to tell reveals the contingency upon which liberal humanist symbols and narratives were elevated and spread. It makes their embrace by (Jewish and gentile) leaders somewhat strange. It even suggests we might similarly look for such strangeness in other corners of postwar American popular culture history, and in doing so, perhaps sunder the contemporary mystique of American liberalism.

Andrew Paul is a historian and an adjunct assistant professor of humanities at the University of North CarolinaAsheville. His research investigates the roots of postwar liberalism and libertarianism in the popular culture of the early Cold War era. His work has appeared in American Studies and the Journal of Popular Film and Television. He has also written for In These Times and the Washington Post.

\footnotetext{
79“Movie Makers Advised on Minorities by Expert," Los Angeles Times, May 21, 1961, J19.

${ }^{80}$ Schultz, Tri-Faith America.
} 